\title{
HOST CASTRATION AS A PARASITIC STRATEGY
}

\author{
Marto Baudotn \\ Department of Zoology, The University of Michigan, Ann Arbor, Mich. 48104
}

Received April 29, 1974

The "destruction or alteration of (the host's) gonad tissue by parasites" (Noble and Noble, 1971) is widely referred to as parasitic castration. It is often accompanied by a modification in the expression of the host's secondary sexual characteristics and may also have a variety of other physiological and behavioral effects. That its effects may have considerable influence upon the life-history of the parasite has been less appreciated.

Parasitic castration has attracted scientific attention ever since it was first reported by Maln (1881) and studied by Giard (1886, 1887, 1889; Giard and Bonnier, 1887). The phenomenon has been reviewed for various groups of host organisms, e.g., Crustacea (Reinhard, 1956; Charniaux-Cotton, 1960), Insecta (Wülker, 1964), and Mollusca (Koie, 1969; Cheng, 1971; Wright, 1971), as well as for groups of parasites, e.g., Nematoda (Welch, 1965) and Turbellaria (Jennings, 1971). Its importance has recently gained recognition in a number of parasitology textbooks (e.g., Caullery, 1952; Cheng, 1972; Noble and Noble, 1971).

Several explanations of parasitic castration have been proposed. McClelland and Bourns (1969), for example, consider it to be primarily an adaptive response of the host, and they use a group-selection argument for their explanation:

\footnotetext{
"We feel that the inhibition of molluscan reproduction by trematode parasites must be regarded as a major adaptation which serves on the one hand to spare snails from the double burden of producing both eggs and cercariae and on the other hand as a resources-management device whereby one portion of the snail population serves its own kind and the parasites by reproducing, while the remainder serves the parasites by incubating cercariae over an extended period of time." (op. cit., p. 145).
}

Such interpretations have been rejected by Rothschild (Rothschild and Clay, 1952) who remarks that:

\begin{abstract}
"In the case of larval flukes it is worth remembering that there can be no gradual adaptation between host and parasite. Selection is entirely one-sided. The parasite castrates the host or, in the case of young snail hosts, inhibits the growth of the gonads, and therefore the more susceptible snails, and even those which survive infection the most successfully, do not reproduce themselves and are eliminated from the population. Consequently adaptation can only be on the side of the parasite. In the cases of larval flukes this situation is very obvious, but it probably exists in many other cases of parasitism, when it is wrongly assumed that adaptation is mutual." (op. cit., p. 35).
\end{abstract}

Rothschild $(1941 b, c)$ proposed increased host growth as the selective advantage of parasitic castration for trematodes castrating their first intermediate host, Peringia ulvae. She demonstrated a positive correlation between frequency of parasitism and host size, which led her to postulate that parasitized hosts grew faster and to a larger size than non-parasitized ones. This, she said, should result in increased fitness of the parasite, since the number of cercariae produced by a snail is proportionate to its size. However, an alternative hypothesis to that of increased host growth has been offered by Hartnoll (Hartnoll, 1967), to explain crustacean castration. He postulated that the typical sacculinization effects are produced by the parasite, which benefits from the resulting physiological and behavioral changes. These changes apparently result in all parasitized individuals, regardless of sex, behaving like ovigerous females; such individuals do not reproduce while they are parasitized, but they provide protection and ventilation to the parasites which occupy the external location usually 
taken by the host's eggs. But this explanation applies only to cases in which the parasite occupies the position of the host's offspring and might thereby benefit from the host's maternal behavior; most cases of parasitic castration do not fall under this category, and it certainly does not explain the "masculinization" of stylopized (parasitized by Strepsiptera) Andrena (Perez, 1886; Salt, 1927, 1931).

Although these and other explanations have been offered for particular instances of parasitic castration, discussions of the subject to date fail to provide any general hypothesis or unifying interpretation of the phenomenon's adaptive significance. This paper attempts to supply such an interpretation in terms of fitness of parasites.

In developing this interpretation, I suggest that host castration can be viewed as a strategy of the parasite. By strategy I mean a sequence of physiological or behavioral states of a genotype which result in a modification of a factor or factors determining the fitness of that genotype. The persistence of the strategy in the organism's population being determined by its effects on individual fitness (i.e., its optimization). Basically this strategy involves a curtailment of the "reproductive effort" of the host. Reproductive effort can be defined as that portion of the total resources, utilized at a given time, which is devoted to reproduction (Gadgil and Bossert, 1970; Williams, 1966a,b). This effort may have a "cost" in terms of future reproduction, if the current expenditure of time and/or energy resources reduces survivorship and/or future fecundity (Williams, 1966b; Fisher, 1958). Organisms will tend to develop schedules of reproduction such that future loss will on the average be balanced by gains in fitness due to present investment (Williams, 1966b). Characteristics which result in increased investment in reproduction at no future cost will always be selectively advantageous and are therefore uninteresting in the present context. However, present reproductive effort involving some future cost will be selected in proportion to fitness gained by that investment as compared to the cost. Both gain and cost may be dependent upon the demographic environment of the organism; at any time, an organism faces the decision whether or not to spend effort in reproduction and, if so, how much effort to spend. (This decision may be either a facultative or a fixed response, depending on the predictability and variability of the demographic environment.)

Given these assumptions, one might predict that, in a host which has attained such an adaptively balanced schedule of reproduction, any characteristic which reduces reproductive effort will likely increase the energy available for non-reproductive purposes. These purposes, which include fat storage and growth, could result in an increase in the host's survivorship. For example, in his experiments with Agonum fuliginosum and $A$. thoreyi Murdoch (1966) found that, "other mortality factors being of equal intensity, the survival of adult female Carabidae, from near the end of one breeding season to the start of the next, is inversely proportional to the amount of reproduction in that first breeding season." Similar results have been obtained for barnacles (Barnes, 1962), domestic cats (Hamilton et al., 1969) and man (Hamilton, 1948). In this connection, it should be noted that sterile mutant Drosophila show an increase in lipid content of the body fluids and in fat deposition (Doanne, $1960 a, b)$. Furthermore, an increase in weight of castrated domesticated animals is well known.

Castrating parasites may therefore use to their own advantage the results of a reduction in the host's reproductive effort. By interfering with host reproduction, they may gain the advantages derived from increased host survivorship (Goertz, 1966; Wecker, 1961), increased host growth (Cheng, 1971), and/or increased energy availability (Hughes, 1940; Kornhauser, 1919). My postulate is, therefore, that parasitic castration can be seen as an adaptation resulting in increased fitness of the 
TABLE 1. The effects which have been observed in a broad spectrum of parasite-host interactions.

\begin{tabular}{|c|c|c|c|c|c|c|c|c|c|}
\hline \multirow[b]{3}{*}{ Parasite } & \multirow[b]{3}{*}{ Host } & \multicolumn{5}{|c|}{ Effects on the host } & \multirow{3}{*}{$\begin{array}{l}\text { Means } \\
\text { of } \\
\text { castra- } \\
\text { tion }\end{array}$} & \multirow{3}{*}{$\begin{array}{l}\text { Kin- } \\
\text { ship } \\
\text { of } \\
\text { castra- } \\
\text { tors }\end{array}$} & \multirow[b]{3}{*}{ Source } \\
\hline & & Gonads & Growth & $\begin{array}{r}\text { Sur } \\
\mathbf{S}\end{array}$ & $\begin{array}{l}\text { vor- } \\
\text { p }\end{array}$ & $\begin{array}{l}\text { Sec. } \\
\text { sex. } \\
\text { char. }\end{array}$ & & & \\
\hline & & 90 & q & 웅 & $\sigma^{7}$ & $\sigma$ & & & \\
\hline
\end{tabular}

Protozoa

Phytomastigophora

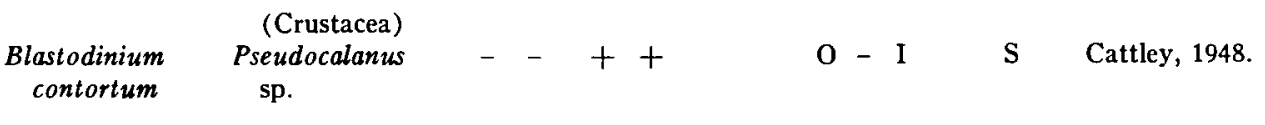

Telosporea

$\begin{array}{cccccc}\text { (Crustacea) } & & & & & \\ \text { Agregata } & \text { Inachus } \\ \text { inachi } & \text { dorsetensis } & - & - & \text { D } & \text { Smith, } 1905 .\end{array}$

Microsporidea

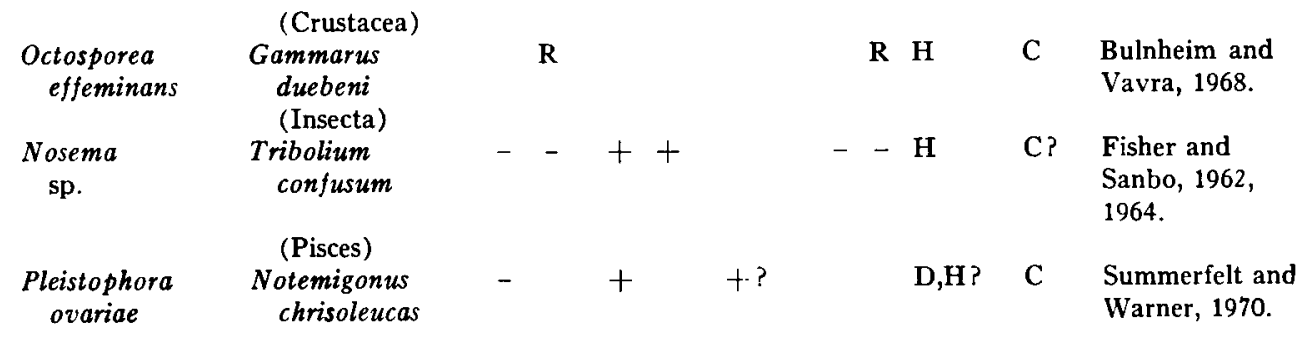

Ciliatea

Orchytophrya
stellarum
Ellobiopsidae

(Asteroidea)

Asterias

rubens

D M? Vevers, 1951.

Thalassomyces fagei

(Crustacea)

Thysanoesa

$-\quad+?+?+?+?--$ H?,I S

Hoffman and

Yanc, 1966; raschi

Mauchline, 1966.

Mesozoa

Orthonectidea

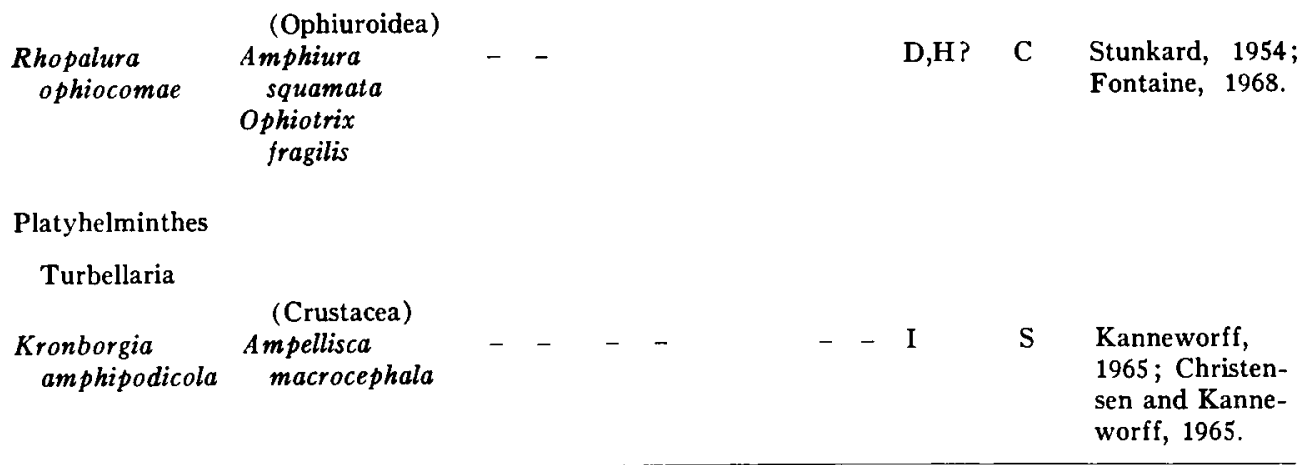


TABLE 1. (continued)

\begin{tabular}{|c|c|c|c|c|c|c|c|c|c|c|}
\hline \multirow[b]{3}{*}{ Parasite } & \multirow[b]{3}{*}{ Host } & \multicolumn{6}{|c|}{ Effects on the host } & \multirow{3}{*}{$\begin{array}{c}\text { Means } \\
\text { of } \\
\text { castra- } \\
\text { tion } \\
\end{array}$} & \multirow{3}{*}{$\begin{array}{c}\text { Kin- } \\
\text { ship } \\
\text { of } \\
\text { castra- } \\
\text { tors } \\
\end{array}$} & \multirow[b]{3}{*}{ Source } \\
\hline & & \multicolumn{2}{|c|}{ Gonads } & Growth & $\begin{array}{l}\text { Survivor- } \\
\text { ship }\end{array}$ & \multicolumn{2}{|c|}{$\begin{array}{l}\text { Sec. } \\
\text { sex. } \\
\text { char. }\end{array}$} & & & \\
\hline & & $q$ & $\sigma$ & 90 & 웅 & 운 & $\sigma$ & & & \\
\hline \multicolumn{11}{|l|}{ Trematoda } \\
\hline & (Gastropoda) & & & & & & & & & \\
\hline $\begin{array}{l}\text { Trichobilharzia } \\
\text { ocellata }\end{array}$ & $\begin{array}{l}\text { Limnaea } \\
\quad \text { stagnalis } \\
\text { (Gastropoda) }\end{array}$ & - & & + & + & & & $\mathbf{H}$ & C & $\begin{array}{l}\text { McClelland and } \\
\text { Bourns, } 1969 .\end{array}$ \\
\hline $\begin{array}{l}\text { "Metacercaria } \\
\text { A" }\end{array}$ & $\begin{array}{l}\text { Littorina } \\
\quad \text { neritoides }\end{array}$ & $(-)$ & $(-)$ & $(-)(-)$ & $(-)(-)$ & & & $\mathrm{D}$ & $\mathbf{M}$ & $\begin{array}{l}\text { Rothschild, } \\
\text { 1941a; Lysaught, } \\
1941 \text {. }\end{array}$ \\
\hline $\begin{array}{l}\text { "Cercaria } \\
\text { B" }\end{array}$ & $\begin{array}{l}\text { Littorina } \\
\text { neritoides } \\
\text { (Gastropoda) }\end{array}$ & - & - & ++ & $+?+?$ & & & I & $\mathrm{C}$ & $\begin{array}{l}\text { Rothschild, } \\
1941 a \text {. }\end{array}$ \\
\hline $\begin{array}{l}\text { Cercaria } \\
\text { oocysta }\end{array}$ & $\begin{array}{l}\text { Peringia } \\
\text { ulvae } \\
\text { (Gastropoda) }\end{array}$ & - & - & ++ & $+?+?$ & & & I & C & $\begin{array}{l}\text { Rothschild, } \\
1941 b, c .\end{array}$ \\
\hline $\begin{array}{l}\text { Zoogonoides } \\
\text { viviparus }\end{array}$ & $\begin{array}{l}\text { Buccinum } \\
\text { undatum }\end{array}$ & - & - & $+?+?$ & $+?+?$ & & - & D? & $\mathrm{C}$ & Køie, 1969. \\
\hline \multicolumn{11}{|l|}{ Cestoidea } \\
\hline $\begin{array}{l}\text { Diplocotyle } \\
\text { sp. }\end{array}$ & $\begin{array}{l}\text { (Crustacea) } \\
\text { Gammarus } \\
\text { zaddachi }\end{array}$ & - & - & + & & - & & $\mathbf{I}$ & $\mathrm{S}$ & Stark, 1965 \\
\hline \multicolumn{11}{|l|}{ Aschelminthes } \\
\hline \multicolumn{11}{|l|}{ Nematoda } \\
\hline $\begin{array}{l}\text { Mermis } \\
\text { sp. }\end{array}$ & $\begin{array}{l}\text { (Insecta) } \\
\text { Simulium } \\
\text { sp. } \\
\text { (Insecta) }\end{array}$ & - & - & ++ & $+?+?$ & - & - & $\mathrm{H} ?$ & $\mathrm{~S}$ & Strickland, 1911. \\
\hline $\begin{array}{l}\text { Sphaerularia } \\
\text { bombii }\end{array}$ & $\begin{array}{l}\text { Bombus* } \\
\text { sp. }\end{array}$ & & - & & & & & $\mathbf{H}$ & $\mathbf{F}$ & Palm, 1948. \\
\hline \multicolumn{11}{|c|}{ Nematomorpha } \\
\hline $\begin{array}{l}\text { Gordius } \\
\text { sp. }\end{array}$ & $\begin{array}{l}\text { Stauroderus } \\
\text { rammei }\end{array}$ & - & - & + & & & - & $\mathbf{I}$ & $\mathrm{S}$ & Ebner, 1940. \\
\hline \multicolumn{11}{|l|}{ Arthropoda } \\
\hline \multicolumn{11}{|l|}{ Crustacea } \\
\hline $\begin{array}{l}\text { Peltogaster } \\
\text { curvatus }\end{array}$ & $\begin{array}{l}\text { Pagurus } \\
\text { cuanensis } \\
\text { (Crustacea) }\end{array}$ & & & $+?+?$ & $+?+?$ & & & H? & $S$ & Samuelsen, 1970. \\
\hline $\begin{array}{l}\text { Sacculina } \\
\text { bicuspidata }\end{array}$ & $\begin{array}{l}\text { Microphrys } \\
\text { bicornutus } \\
\text { (Crustacea) }\end{array}$ & - & - & $+?$ & $+?$ & & - & $\mathbf{H}$ & $\mathrm{S}$ & Hartnoll, 1967. \\
\hline $\begin{array}{l}\text { Sepiosaccus } \\
\text { rodriguezi }\end{array}$ & $\begin{array}{l}\text { Diogenes } \\
\quad \text { pugilator } \\
\text { (Crustacea) }\end{array}$ & - & - & $+?$ & $+?$ & & & $\mathrm{H} ?$ & $\mathrm{~S}$ & $\begin{array}{l}\text { Bourdon, } 1963 \text {; } \\
\text { Perez, } 1928 .\end{array}$ \\
\hline $\begin{array}{l}\text { Hamiarthrus } \\
\text { abdominalis }\end{array}$ & $\begin{array}{l}\text { Spirontocaris } \\
\text { lilljeborgii }\end{array}$ & - & $\rightarrow$ & $+?+?$ & $+?+?$ & & & I & $\mathrm{S}$ & Pike, 1960. \\
\hline
\end{tabular}

* Sphaerularia bombii produces no external modifications in its host, an insect. This is probably due to the fact that infection takes place once the host is an imago in which all the external characters are already determined. Other cases of castration may be overlooked because of the lack of obvious effect. 
TABLE 1. (continued)

\begin{tabular}{|c|c|c|c|c|c|c|c|c|c|c|c|}
\hline \multirow[b]{3}{*}{ Parasite } & \multirow[b]{3}{*}{ Host } & \multicolumn{7}{|c|}{ Effects on the host } & \multirow{3}{*}{$\begin{array}{c}\text { Means } \\
\text { of } \\
\text { castra- } \\
\text { tion }\end{array}$} & \multirow{3}{*}{$\begin{array}{l}\text { Kin- } \\
\text { ship } \\
\text { of } \\
\text { castra- } \\
\text { tors } \\
\end{array}$} & \multirow[b]{3}{*}{ Source } \\
\hline & & \multicolumn{2}{|c|}{ Gonads } & \multicolumn{2}{|c|}{ Growth } & \multicolumn{2}{|c|}{$\begin{array}{l}\text { Survivor- } \\
\text { ship }\end{array}$} & $\begin{array}{l}\text { Sec. } \\
\text { sex. } \\
\text { char. }\end{array}$ & & & \\
\hline & & $q$ & 8 & $q$ & 3 & 9 & 8 & $0^{\circ}$ & & & \\
\hline Insecta & & & & & & & & & & & \\
\hline & (Insecta) & & & & & & & & & & \\
\hline $\begin{array}{l}\text { Stylops } \\
\quad \text { mellitae }\end{array}$ & $\begin{array}{l}\text { Andrena } \\
\text { nigroaena } \\
\text { (Insecta) }\end{array}$ & - & & & & $+?$ & & - & I & $\mathrm{S}$ & $\begin{array}{l}\text { Smith and } \\
\text { Hamm, } 1914 .\end{array}$ \\
\hline $\begin{array}{l}\text { Elenchus } \\
\quad \text { tenuicornis }\end{array}$ & $\begin{array}{l}\text { Javasella } \\
\quad \text { pellucida } \\
\\
\text { (Mammalia) }\end{array}$ & - & - & - & - & & & - & $\mathrm{H}$ & $\mathrm{S}$ & $\begin{array}{l}\text { Raatikainen, } \\
\text { 1966; Baumert- } \\
\text { Behrisch, } 1960 .\end{array}$ \\
\hline $\begin{array}{l}\text { Cuterebra } \\
\text { angustifrons }\end{array}$ & $\begin{array}{l}\text { Peromyscus } \\
\text { leucopus }\end{array}$ & & - & & & & + & & $\mathrm{D}, \mathrm{H}$ ? & $\mathbf{S}$ & Wecker, 1962. \\
\hline $\begin{array}{l}\text { Cuterebra } \\
\text { sp. }\end{array}$ & $\begin{array}{l}\text { Peromyscus } \\
\text { leucopus }\end{array}$ & & - & & & + & + & & $\mathrm{D}, \mathrm{H}$ ? & $\mathrm{S}$ & Goertz, 1966. \\
\hline $\begin{array}{c}\text { Cuterebra } \\
\text { grisea }\end{array}$ & $\begin{array}{l}\text { Peromyscus } \\
\quad \text { maniculatus }\end{array}$ & & & & & + & + & & $\mathrm{D}, \mathrm{H}$ ? & $\mathrm{S}$ & $\begin{array}{l}\text { Hunter et al., } \\
1972 .\end{array}$ \\
\hline
\end{tabular}

Symbols used in the table: +, indicates an enlargement of, or increase in, characteristic; -, reduction of characteristic; ?, nature of effect, means of castration, or kinship of castrator inferred from what is stated in source; $\mathrm{O}$, no observed effect; (), effect apparent only in heavy infections; $\mathrm{I}$, indirect castration, either hormonal or nutritional; $\mathrm{D}$, direct castration; $\mathrm{H}$, hormonal castration; $\mathrm{S}$, single parasites can and usually are responsible for castration; $\mathrm{C}$, the of fspring resulting from asexual reproduction of a parasite are responsible for castration; F, the sexually produced of fspring of a parasite are responsible for castration; $\mathbf{M}$, multiple genotypes are probably responsible for castration; $\mathbf{R}$, functional sex reversal.

parasite; this increased fitness is a consequence of the improved environment due to host castration.

\section{Direct Effects of Parasitic Castration on the Host}

Before proceeding further, it seems useful to provide a brief but broad survey of the direct effects of parasitic castration upon the host organism. Table 1 summarizes the effects which have been observed in a broad spectrum of parasite-host interactions. I have tried to ascertain what means of castration are utilized by each parasite and what genetic relationship is most likely between parasites in the same individual host. The relevance of these considerations to this paper will be dealt with below (p. 346 and p. 347). The examples used in Table 1 are only a small though, I believe, representative sample of those found in the literature. I have tried to include as many groups of para- sites as possible while still restricting the examples to those where interference with host reproduction is likely to be a parasite's adaptation. All the examples in the table with the exception of Octosporea effeminans have at some time been reported as "parasitic castration." I have included $O$. effeminans in the table since I believe that it can shed some light on the conditions under which parasitic castration is not likely to evolve (see p. 345). Both "Metacercaria A" and Orchytophrya stellarum are examples of parasites which castrate their hosts but in these cases parasitic castration may not be the result of a parasite's adaptation (see p. 346). These two last examples were included in order to contrast their characteristics with those of the other, more typical, castrators.

The principal direct effects of parasitic castrators on their hosts can be classified as effects on a) secondary sexual characteristics; b) internal organs; c) internal 
secretions; d) viability and growth; e) behavior; f) reproduction; and g) sex reversal. The magnitude of these effects depends on a variety of factors, including the host's sex.

\section{Effects on the Host's Secondary Sexual Characters}

Perhaps the most obvious result of parasitic castration is a modification of the secondary sexual characters of the host. The subject has been intensively studied in Insects and in Crustacea. The reviews by Reinhard (1966), Wülker (1964), Charniaux-Cotton (1960), Wheeler (1910), Salt $(1927,1931)$ cover the subject adequately. The following generalizations can be arrived at on the basis of available literature. Host secondary sexual characters are usually modified in such a way that parasitized organisms of different sexes are more similar than are those of the corresponding nonparasitized organisms (Reinhard, 1966; Wuilker, 1964). The effect on secondary sexual characters usually can be interpreted as juvenilization of the host (Reinhard, 1956; Wülker, 1964), the exceptions being cases where the parasite is external and occupies the location of the eggs in eggbearing females, e.g., sacculinization (parasitization by sacculinid crustacea) of some crabs (Hartnoll, 1967). Secondary sexual characters directly involved in mating or finding a mate are in some cases reduced in size (Rempel, 1940; Nielsen, 1970; Hartnoll, 1962, 1967). Secondary sexual characters involved in competition for mates are also usually reduced in size and their condition is more similar to those found in nonaggressive conspecifics (Reverberi, 1943; Baffoni, 1948).

Secondary sex characters which serve as trophic structures involved in provisioning for the offspring, such as the scopa of $A n$ drena, may also be reduced (Perez, 1886; Salt, 1927, 1931; Smith and Hamm, 1914).

\section{Effects on the Internal Organs of the Host}

Parasitic castration, by the definition given, involves a modification of the host gonads. The degree to which gonads are modified varies from a small reduction in size (Baumert-Behrisch, 1960; Welch, 1959; Christie, 1936) to total atrophy (Perez, C., 1933; Salt, 1927, 1931). Parasites responsible for parasitic castration may also have profound effects on organs other than the gonads (Matsumoto, 1952, 1953; Fischer, 1928). Castrators can be divided into three groups according to their effects on the internal organs of the host (Noble and Noble, 1971).

1) Castrators which have a direct effect on a number of organs including the gonads (e.g., metacercariae).

2) Castrators which have a direct effect on the gonads but have little effect on other organs (e.g., Rhopalura).

3) Parasites which have little direct effect on the gonads but where there is a strong positive correlation between presence of the parasite and a reduction of the gonads (e.g., Eoxenos, Hemiarthrus).

This last case seems to be the most common, at least in Insect and Crustacean hosts (Caullery, 1952; Reinhard, 1956; Wülker, 1964) (see Table 1).

\section{Effects on the Host's Internal Secretions}

Parasitic castration is often accompanied by changes in the internal fluids of the host. The literature covering this aspect of parasitic castration has been reviewed by von Brand (1952); Fisher (1963); Cheng and Snyder (1962); Cheng (1971). No generalizations can be made for the effects of castrators on the internal environment of their hosts, but I consider that the following observations are important in the present context. In some cases, parasitic castration results in an increase in lipid content of the internal fluids of the organism (Hughes, 1940; Kornhauser, 1919; von Brand, 1952; Reinhard, 1956). An increase in fat depositions has been reported in other cases (Welch, 1959; Robson, 1911; Rudloff and Veillet, 1954; Smith, 1913). Some castrators have been 
shown to secrete hormones into the host's internal environment (Denner, 1968; Fisher, 1963). Castrators have been shown to attack directly or to interfere with the host's endocrinological organs (Matsumoto, 1952; Palm, 1948; Brandenburg, 1953, 1956; Hattingen, 1956). In some cases, the presence of the castrator does not result in any detectable modification of the host's fluids (Reinhard, von Brand and McDuffie, 1947).

Charniaux-Cotton in an extensive review (1960) of the literature on parasitic castration in Crustacea concluded that parasitic castration in this group is accomplished by the parasites' interference with the secretions of the androgenic gland of the host (op. cit., p. 431).

\section{Effects on Host Viability and Growth}

Field data on the effects of castrators on host viability are almost totally lacking. Growth data of individual castrated hosts are also lacking. There are, however, a number of studies that show a positive correlation between frequency of infection and host size (Allen, 1966; Hartnoll, 1967; Pike, 1960; Rothschild, 1936, 1938, 1941a, $b, c$; Koie, 1969; Stark, 1965; Bourdon, 1963; Mauchline, 1966; Addel-Malek, 1952). The following alternatives could produce such correlation:

1) The castrator is more likely to infect large hosts.

2) The castrator produces an increase in host growth.

3 ) The castrator reduces mortality without affecting growth.

4) All host sizes are equally likely to be infected per unit time and host size increases with age.

5) The castrator has a size-dependent effect on behavior and it increases the catchability of the larger hosts.

6) The castrator causes a high mortality of the smaller (younger) hosts.

Unfortunately, the data available usually do not allow us to choose among these pos- sibilities. However, laboratory studies have definitely shown that at least in some cases parasitic castration results in increased host growth (Rothschild and Rothschild, 1939; McClelland and Bourns, 1969) and viability (McClelland and Bourns, 1969). Also available are field data indicating an increase in host viability in castrated hosts (Goertz, 1966; Wecker, 1962). A much more common report is the absence of obvious pathological conditions which would imply reduced viability.

\section{Effects on Host Behavior}

The effects of parasitic castration on host behavior have seldom been investigated and most of the information is inferential. The following are some relevent observations. Stylopization may result in drastic changes in host behavior. Salt (1927, 1931); Perez (1886) and Smith and Hamm (1914) reported that stylopized female Andrena bees had reduced scopae and that they seldom if ever carried pollen. Nonparasitized bees were on the other hand almost always found to be carrying pollen.

Stylopized digging wasps (Chlorion, Sphex) show smooth and unworn jaws while normal females show worn and scratched mandibles (Salt, 1931).

The control of dominance hierarchies in shore crabs (Cyclograpsus punctatus) has been shown (Caiger and Alexander, 1973) to be determined by the action of the androgenic gland. This gland is interfered with by castrators and therefore one can expect that parasitic castration would result in a reduction in the aggressive behavior (op. cit., p. 139) characteristic of dominant males.

Sacculinized male and female shore crabs (Carcinus maenas) stay in deep water while nonparasitized males migrate to and remain in shallow water. Normal females go to shallow water in order to mate (Rasmussen, 1959). After mating, ovigerous females return to deep water.

Simuliid larvae parasitized by Mermis sp. show a reduction in mobility and an 
increase in the ability to collect food (Strickland, 1911).

Parasitized male chironomids show a reduction in the complexity of their antennae and tarsi (Rempel, 1940). This reduction suggests either a reduction in their matesearching behavior or a reduction in their ability to find mates. Normal chironomids use their antennae in sound detection.

Mermithized ants remain in the nest and do not forage like uninfected ants; neither do they tend the offspring (Wheeler, 1910).

Stylopized colonial Hymenoptera show a reduction in brood care (Siebold, 1843). Similarly worker honey-bees, infected with Nosema apis, do not tend the brood (Wang and Moeller, 1970).

These observations suggest that parasitic castration often results in changes in host behavior which involve a reduction in sexual or parental activities.

\section{Effects on Host Reproduction}

The effects of castrators on secondary sexual characteristics, internal organs, internal secretions, and behavior of the host indicate that reproduction is reduced drastically. In most cases it is safe to assume that there is no host reproduction for most of the time of infection. Not only is gamete production curtailed but all aspects of reproductive behavior and reproduction related growth are reduced. The reduction in the reproductive expenditure of the host is usually much larger than is apparent from consideration of only one of the variables involved.

In hosts which show the effects of parasitic castration, the amounts of time and energy devoted to reproduction are greatly reduced; again, the only exceptions involve cases where the parasite derives a direct benefit from the particular reproductive behavior or structure (Hartnoll, 1967; Bulnheim and Vavra, 1968; Reinhard, 1956; Wülker, 1964). Permanent sterility is often a result of parasitic castration. Even in those cases were parasitic castration does not result in permanent sterility the reduction in host fecundity is considerable (Pike, 1960).

\section{Sex Reversal}

Even though the literature mentions many cases of presumed sex reversals due to parasitic castration (Cattley, 1948; Rempel, 1940; Potts, 1906; Okada and Miyashita, 1935), most of them could equally well be interpreted as retention of juvenile characteristics (Brandenburg, 1953; Reinhard, 1956; Wülker, 1964). This statement cannot be applied to cases of parasitism of holometabolous insects, since the immature is a larva not at all like the adult. That secondary sexual characters in insects are reduced in their expression is, however, analogous to the retention of juvenile structures in other host groups. Exceptions to this generalization are the speeding up of development of some hosts (e.g., Andrena: Perkins, 1918) and the acquisition of typical female structures and physiological characteristics by some Crustacea (Hartnoll, 1967). Parasitic castration does not result in true functional sex reversal (Reinhard, 1956; Wülker, 1964). The effects of Octosporea effeminans on Gammarus duebeni (Bulnheim and Vavra, 1968) constitute the only case of functional sex reversal that I have come across. The reasons for this exception will be dealt with below.

Parasitic castration effects are highly dependent on host sex. Which of the sexes is more obviously modified seems to depend more on the host than on the parasite. For instance, in Hymenoptera, the females are usually more modified than the males, whether they are parasitized by Strepsiptera (Salt, 1931) or by Mermithidae (Kloft, 1949). In chironomids, males seem to be more obviously affected (Wülker, 1962). In Crustacea, males seem to be more modified than females but the degree to which they are is parasite dependent (Reinhard, 1956; Nilsson-Cantell, 1926).

The modification of host gonads is also sex dependent. In most cases, the male's gonads are less modified than the female's (Wülker, 1961; Reinhard, 1942; Brandenburg, 1953). 


\section{Characteristics of Castrators}

\section{Size and Energy Relationships}

The literature does not often afford data on the relative size of castrators and their hosts. The available references indicate that castrators are unusually large parasites (Kuris, 1974). In general castrators constitute $1-10 \%$ of the weight of their hosts (Kuris, 1974). This relationship applies to individual parasites when individuals are usually responsible for castration of their hosts. When castration is usually accomplished by a clone or by descendants of a propagule, then the combined weight of the group is of that magnitude (Woodhead, 1930). If one assumes that the energy requirements of parasites are proportional to their mass, then one can say that castrators have unusually large energy requirements.

\section{Means of Castration}

Host castration can be the result of different actions by the parasite. Depending on the immediate cause, parasitic castration can be either a) direct, b) indirect nutritional, or c) indirect hormonal.

a) Direct ingestion and/or direct mechanical interference with the gonads occurs in a few cases (Perez, 1933; Summerfelt and Warner, 1970; Einarsson, 1945). In some, the parasite damages the gonads in conjunction with other organs (Atkins, 1933; Koie, 1969; Cheng and James, 1960 ), while in others the damage is restricted to the gonads (Lichtenstein, 1921). The sequence in which the organs are damaged may vary: in some cases, the gonads are the first organs attacked, and other organs are attacked only much later (Prescott, 1960; York and Prescott, 1952); in other cases, the gonads are damaged after other organs are affected (Lysaught, 1941).

b) Indirect castration through withdrawal of nutrients has often been claimed as the immediate cause of parasitic castration (Salt, 1927, 1931; Reinhard, 1956). For some of the cases involved, alternative explanations have been proposed (Wülker, 1964; Reinhard, 1956). Nutritional cas- tration cannot, however, explain gigantism and increased lipid concentration in the haemolymph of castrated animals, unless it involves a very selective withdrawal of key nutrients.

c) Indirect hormonal castration has been asserted in a number of instances (Palm, 1948; Veillet and Graf, 1958; BaumertBehrisch, 1960) and, as was mentioned before, the secretion of "castrating" hormones has been demonstrated in the laboratory.

\section{Kinship of Castrators in the Same Individual Host}

Parasitic castration is almost invariably produced either by single parasites or by their immediate offspring. Some studies (Altes, 1962; Veillet, 1945) have shown that in some cases castrators are associated with conspecifics less frequently than expected by chance alone. These observations indicate that parasitic castration is usually produced either by single genotypes or by very closely related genotypes. It is unusual to find castration (Table 1) produced by a number of unrelated genotypes. Metacercarial infections in snails are exceptions (Rothschild, 1941a; Lysaught, 1941; Hoshina and Ogino, 1951). In these cases, however, parasitic castration may be incidental (cf. p. 348).

\section{Parasite Fecundity and Host Size}

If one assumes that the fecundity of a parasite is proportional to its size, then parasite size can be taken as an index of parasite fecundity. Given this assumption, a positive correlation of host size and parasite size would imply a positive correlation between host size and parasite fecundity.

Some studies on Crustacea have in fact shown a positive correlation between host and parasite sizes. This same relationship has been observed in trematode infections of mollusca (Rothschild, 1936, 1938, 1941a; Abdel-Malek, 1952). Rothschild also observed that the number of cercaria produced by a snail was proportional to 
its size (Rothschild and Rothschild, 1939). Similar results have been obtained for Crustacea (Allen, 1966; Pike, 1960).

\section{Discussion}

\section{Benefits to the Parasite}

The benefits that a parasite may derive from host castration include a) increased energy availability, b) increased host viability and c) increased host growth.

a) Increased energy availability. Parasitic castration often results in an increase in lipid concentration or deposition in the host. This has obvious potential advantages for the parasite if the latter can utilize lipids in the production of offspring. That some parasites may indeed be able to utilize these nutrients in this way is suggested by the fact that some castrators responsible for increased lipid concentration in their hosts have themselves a high lipid concentration (e.g., Gyge branchialis, Hughes, 1940). The detectable concentration of lipids in the host will, however, depend on the intensity of the lipid utilization by the parasite (e.g., Peltogaster paguri, Reinhard, 1942). For this reason, low lipid concentration in the host (e.g., Pagurus, Reinhard and von Brand, 1944) does not indicate that castration has not resulted in increased energy available to the parasite. A similar argument could be pursued to explain increases in glycogen (Hughes, 1940) in castrated host body fluids.

b) Increased host viability. Reproduction may involve a number of risks and energy expenditure for the host. Sexual maturation, territory maintenance and acquisition, nest building, competition for mates, mating, nourishment and protection of the young are all activities that may involve great energy expenditure and risks. Parasitic castration, if it results in reduced host reproductive effort, could bring about reduced host mortality and thus increased host viability. An increase in host viability would often be advantageous to the parasite. It might mean an increased probability of the parasite reaching reproductive age and/or an increased number of reproductions. It might also mean an increased probability of completing the parasite's own life cycle.

Parasitic castration has been shown to result in changes in the host's sexual behavior and in a reduction of secondary sexual characteristics associated with sexual behavior. These activities probably involve large amounts of risk and energy expenditure (Williams 1966a,b; Trivers, 1972) and their suppression might result in increased host viability. Whether these modifications result in an absolute gain in host survivorship will depend on the demands made by the parasite. Castrated hosts may have lesser viability than non-parasitized hosts but as long as they have greater viability than parasitized hosts which are not castrated, parasitic castration will be adaptive for the parasite. The often reported positive correlation of host size (age?) and frequency of parasitism could be due to increased host survivorship (Table 1).

c) Increased host growth. Even though the field data are not conclusive, laboratory studies show that parasitic castration may lead to increased host growth. This increased host growth could be advantageous to the parasite for the following reasons: a) there may be a positive correlation between host size and parasite fecundity; b) increased host size may mean greater host viability through predator avoidance or defense; and c) greater host size may result in greater energy available to the parasite provided that the larger host is also a better competitor.

\section{Costs of Castration}

The parasite's secretion of hormones and/or development of structures involved in castration requires energy. That energy could be used by the parasite for reproduction. In this sense, parasitic castration has a cost for the parasite. In order for parasitic castration to be adaptive, this cost has to be outweighed by the benefits resulting from parasitic castration. The literature does not allow any quantitative 
estimation of this cost of castration. But the constant secretion of antagonistic hormones that is necessary to upset the normal physiological feedback mechanisms of a host which is an order of magnitude larger than the parasite is probably quite expensive if the hormones are manufactured solely for that purpose. The cost may be much reduced if these hormones are the metabolic byproduct of other activities. Even if the costs are large, these could still be offset by adequate increases in host viability, growth and/or energy availability for the parasite.

Besides this energetic cost, parasitic castration also has a cost in terms of the host's offspring. These offspring are after all prospective hosts for the parasite's own offspring. In a sense, then, the parasite reduces its own fitness by castrating its host. However, as far as selection is concerned, individual fitness is meaningful only when compared to that of other individuals with alternative genotypes. If parasitic castration results in lowered host availability to other individuals in the parasite population, then parasitic castration may still be selected for. If the host's offspring are equally available to all the genotypes in the parasite's population, then parasitic castration would not result in any reduction in the castrator's relative fitness, since this reduction would be equal for all individuals in the parasite's population. Only if the host's offspring were more available to the castrator than to alternative genotypes would parasitic castration be disadvantageous. Even in this case, the effect of parasitic castration on the parasite's fitness would be the difference between this reduction and the gains due to increased host growth, survivorship and energy available to the parasite.

One of the factors affecting the availability of the host's offspring to the parasite is the developmental time of the host. If the offspring of the host, at the time of prospective castration, develop so slowly that they are susceptible to parasitism well after the parasite has reached the infective stage, then they are effectively unavailable to that parasite. Host offspring produced before the time of parasitism are not relevant since they cannot be considered a cost. Castration would less likely be adaptive if parasite transmission could occur between adult and neonate host. Only in the cases where the parasite is restricted to the host's offspring will parasitic castration of necessity be nonadaptive. Then selection would favor any characteristic that induced the host to spend more energy in reproduction, once the parasite is infective. This selection would occur even if it might result in reduced fitness of the host. Such is the case in Gammarus duebeni parasitized by Octosporea effeminans (Bulnheim and Vavra, 1968). O. effeminans can be transmitted almost exclusively transovarially. Infected $G$. duebenni females produce only female offspring while noninfected produce an equal sex ratio in their offspring. This increases the number of hosts available for the parasite's offspring but is unlikely to increase the host's fitness.

\section{Influence of Host Life History}

If parasitic castration is indeed an adaptive action on the part of the parasite, having the function of reducing the host's reproductive effort, then one would expect that the effects of castration would depend on variables affecting this reproductive effort. One would also expect parasitic castration to be more prevalent in hosts which are spending large amounts of reproductive effort while they harbor the parasite. Since the advantages of parasitic castration would be directly proportional to host reproductive effort, castration of nonreproductive hosts would result in no benefit to the parasite unless parasitic castration resulted in growth or maturation changes beneficial to the parasite. Most cases of parasitic castration result in definite changes while the parasite is in the host (Reinhard, 1956; Wülker, 1964). If parasitic castration has the function of reducing host reproductive effort for the parasite's benefit, then one 
would expect the effects of parasitic castration to depend on the host's sex, since this effort will take different forms in each sex (Trivers, 1972). Females in general spend more calories per individual gamete than do males (op. cit.). Thus we see that testes are often not reduced while the ovaries are (Wülker, 1964). On the other hand, males may spend large amounts of time and energy in the defense of territories and in aggression with other males (op. cit.). Here we see that secondary sexual characteristics involved in territoriality (chelae of Crustacea) tend to be reduced more in the castrated males than in the females (Reinhard, 1956). Females, however, may be involved in long-term parental care while males may have a much shorter reproductive season. In such cases, we find a reduction in those female secondary sexual characteristics and behavior involved in parental care (Salt, 1927, 1931). For all these considerations, the host phenotype that results in the optimum parasite fitness would often be more similar to one of the normal host sexes than to the other and would combine characters that result in high host survivorship and/or low energy expenditure. Such a phenotype cannot be that of a normal host, since it would be that of a nonreproductive individual with a fitness of near zero.

\section{Influence of Parasite's Life History}

The effect that host survivorship and growth and the availability of energy have on a parasite will depend on the length of time that the parasite is in the host. How long a parasite remains in a host will be determined by factors that are not necessarily modifiable by the parasite. Some such factors may be seasonal host availability or seasonality of the external environment. The longer the time spent in the host, the greater the chance that the parasite will be affected by the mishaps of the host and the greater the opportunity for the parasite to influence the host. Therefore, the intensity of selection for host modification and the chance of that modification occurring are proportional to the time that a parasite spends in a host.

The advantages herein postulated for parasitic castration may become irrelevant to the parasite once the parasite has completed development in that host. At that time, it may even become advantageous to utilize as much of the host tissues as possible, as shown by castrators which could be classified as parasitoids (Christensen and Kanneworff, 1965; Kurochkin, 1960). The parasites may also increase the probability of the host's dying if the death of the host results in increased parasite fitness. Thus the parasite may increase the likelihood of predation by the appropriate predators, i.e., those that are hosts for the next stage in the parasite's life cycle (Holmes and Bethel, 1972).

\section{Means of Castration}

Most of the literature on parasitic castration has not been concerned with the ultimate causes of parasitic castration. The concentration has been mainly on the immediate causes or means of castration. As far as the parasite is concerned, parasitic castration is advantageous irrespective of the means used. It is only the energetic expenditure in the different means that is relevant. Those methods that are energetically cheaper would be more advantageous to their possessors. Which method is actually used will, however, depend in large manner on the evolutionary history of the parasite. It may be energetically more economical to ingest a sex determining gland than to secrete large amounts of an antagonistic hormone. However, the latter may be the situation found in nature because parasitic castration may have evolved as a result of the effects of some parasite metabolites on the host. All parasites require energy from their hosts and if we assume that any substantial withdrawal of energy would result in reduced fecundity of a host, then a large number of parasites could be considered castrators. Reduced host reproductive effort would then be an almost unavoidable result of parasitism. 
All reductions of host reproductive effort cannot then be considered the result of a parasite's adaptation. Nutritional castration would be a type of castration that may not necessarily be an adaptation since one can hardly envision a parasite not requiring nutrients. Similarly, direct castration through organ ingestion could be considered incidental to the benefits derived from the castration act itself. In either case, parasitic castration may involve adaptation in the form of nutrient choice and selective attack of host organs. The sequence in which tissues are infected may itself be adaptive. In any event, one would also expect that in some cases, parasitic castration may be the incidental result of parasitism. However, on the whole, the literature supports my contention that parasitic castration is often a parasite's adaptation for the following reasons:

1) Most cases of parasitic castration are of the indirect type and many involve hormones.

2) Many cases of direct castration are the result of a very select attack on sex determining organs.

3) The effects of parasitic castration are beneficial to the parasite but not to the host (for exceptions see p. 348).

4) The effects of parasitic castration are extremely predictable within each group of hosts even if the means of castration and the castrators may be quite different.

\section{The Evolution of Parasitic Castration}

One of the correlates which become apparent when considering parasitic castration is the large size of castrators in relation to their hosts when compared to other parasites. Castrators are often between one and ten per cent of the mass of their hosts. This is much larger than the common intestinal parasite. The aggregate weight of clones responsible for parasitic castration is around the same magnitude as that of single individuals responsible for castration. These observations may be significant in terms of the evolution of castration for the following reasons:

1) Other things being equal, a large parasite probably spends more time in its host (has to grow more than a smaller one). Therefore, it is more influenced by what happens to the host and has a greater chance of influencing the host.

2) A greater size would result in greater influence on the host through nutrient requirements, metabolite effects or physical damage. This would increase the likelihood that effects on host reproductive effort would develop and that they would be large enough for selection to act upon.

3) A larger parasite size would put the host under greater stress and therefore make relief from stress the more important. Selection for relief from stress would be proportional to stress. One such relief is suppression of reproduction.

4) In cases where unrelated individual parasites exist in the same host, small parasites are more likely to occur as multiple infections than are large parasites-a large number of large parasites would presumably be too heavy a load for the host. Under such conditions it seems that selection would favor those large parasites that can exclude conspecifics, perhaps by eliciting the host's immune responses. It would also favor those parasites that can escape intraspecific competition by increasing rates of development or by reducing age and/or size at maturity. The outcome of selection in this context would be a reduced likelihood of the small parasites evolving as castrators. It would also result in an increased likelihood of the large parasites evolving as castrators.

\section{Genetic Relationship of Castrators to Noncastrators}

In order for parasitic castration to be selected for, castrator genotypes have to derive advantages not possessed by noncastrators. This would not occur when a castrator is in the same host as a noncastrator. Under such conditions, increased host survivorship, growth and increased energy availability would be beneficial to both parasites. Furthermore, the noncastrator would be able to use the energy not spent in castration to increase its own fitness. Parasitic castration would be less likely to be selected for if castrators were always to be found with competing genotypes. It could be selected for only if the frequency of co-existence of the original castrator genotype with noncastrators was low enough to allow a positive fitness for the castrator. 
This may be the reason why today the vast majority of parasites involved in host castration are usually either single individuals or the progeny of a single individual. Furthermore, in parasites with complex life cycles only stages undergoing schizogony are involved in parasitic castration while other stages are usually not. In some cases (e.g., metacercariae), parasitic castration results from the infection of a large number of individuals which are not likely to be related. In these cases, parasitic castration seems to be incidental to the massive destruction of the internal organs of the host (Rothschild, 1941a).

\section{Parasitic Castration as a Host Adaptation}

Even if, by and large, parasitic castration seems to be a parasite's adaptation, it could conceivably develop as a host's response to parasitism under the following conditions:

1) The host is interoparous,

2) The host has an appreciable chance of reproduction after the parasite abandons the host; and

3) The reduction in host fitness due to suppression of reproduction is more than compensated by a proportional increase in the host's viability and/or future fecundity. This increase, resulting from reduced reproduction, is greater the longer the parasite is in the host.

The fitness of a host genotype that suppresses reproduction, in the presence of parasitism, would be proportional to the probability of being parasitized. Hence, parasitic castration is most likely to evolve, as a host's response to parasitism, in hosts which are subjected to high rates of parasitism, at least periodically.

In most cases, parasitic castration does not satisfy the previous conditions. Host reproduction after castration is usually absent; when present, it is usually a very small proportion of that which was lost to castration. As far as I can see, only Peromyscus parasitized by Cuterebra (Table 1) could satisfy these requirements. That parasitic castration may in some cases be a host adaptation does not make it any the less advantageous for the parasite.

\section{Redefining Parasitic Castration}

Parasitic castration cannot be considered simply as a "destruction or alteration of gonad tissues by parasites" because many cases of typical parasitic castration show very little or no damage to the gonads (Wuilker, 1964). The reduction of host reproductive effort is however, apparent in these cases. On the other hand, parasitic castration should not be considered to include all reduction in reproductive effort stemming from parasitism, since this would make parasitic castration almost equivalent with parasitism and, at the least, would include many cases of parasitism that have very little in common with what is normally regarded as parasitic castration.

I suggest that parasitic castration be redefined as "a destruction or alteration of gonad tissue, reproductive behavior, hormonal balance, or other modification that results in a reduction of host reproductive effort above and beyond that which results from a nonselective use of host energy reserves by the parasite."

\section{SUMMARY}

This paper surveys the literature on parasitic castration and attempts to provide an evolutionary interpretation of the phenomenon. Previous explanations are considered and a unifying hypothesis is proposed. The main theses of this paper are (1) that parasitic castration can be viewed as a parasite's adaptation and (2) that advantages derived from this adaptation are a result of a reduction in host reproductive effort; which in turn gives rise to increased host survivorship, increased host growth and/or increased energy available to the parasite, thereby increasing the parasite's Darwinian fitness. A survey of the literature indicates: a) That castration effects on the hosts are beneficial to the parasite but not to the host; b) That the genetic relationship of castrators within individual hosts is such that natural selection at the level of individual genotypes can account for the observed effects; and c) That the widespread 
occurrence of hormonal castration favors the interpretation outlined above.

Incidental castration and the possibility of parasitic castration as a host's adaptation are considered, and a definition of parasitic castration is proposed.

\section{ACKNowledgments}

I wish to specially thank Armand Kuris for sharing with me some of his ideas on parasitic castration. My deepest appreciation to Francis C. Evans and Donald W. Tinkle who were kind enough to plough the early drafts and contributed their comments. Most of the manuscript was read by Stephen P. Hubbell who contributed helpful comments. I also benefited from suggestions made by Douglas Futuyma, Nelson G. Hairston, Jasper Loftus-Hills, Ann Pace and Henry Wilbur. Some of these ideas were discussed in the Graduate and Demography Seminars at the Department of Zoology at The University of Michigan. Margaret Geers contributed time and comments which rendered my English more intelligible. Some of the research was done while holding an Edwin S. George Scholarship.

\section{Literature Cited}

Abdel-Malek, E. T. 1952. Morphology, bionomics and host parasite relations of the Planorbidae (Mollusca-Pulmonata). Ph.D. Thesis Univ. Mich. 226 p.

Allen, J. A. 1966. Notes on the relationship of the bopyrid parasite Hemiarthus abdominalis (Kryer) with its hosts. Crustaceana 10:1-6.

Altes, J. 1962. Sur quelques parasites et hyperparasytes de Clibanarius erythropus (Latreille) en Corse. Bull. Soc. Zool. France 87:88-97.

Atkins, D. 1933. Pinotherion vermiforme Giard and Bonnier, an entoniscid infecting Pinnotheres pisum. Proc. Zool. Soc. London 1933:319363.

Baffoni, G. M. 1948a. Annotazione comparative sull' azione prodotta dai Rizocefali parassiti di Eupagurus prideauxii. Pubbl. staz. zool. Napoli 21:237-255.

BARNES, H. 1962. So-called anecdysis in Balanus balanoides and the effect of breeding upon the growth of calacareous shell of some common barnacles. Limnol. Oceanog. 7:462-473.

Baumert-Behrisch, A. 1960. Der Einfluss des Strepsipteren-Parasitismus auf die Geschlechts- organe einer Homoptere. Zoologische Beiträge (N.F.) 6:85-126, 291-332.

Bourdon, R. 1963. Epicarides et Rhizocephales de Roscoff. Cah. Biol. Mar. 4:415-434.

von Brand, T. 1952. Chemical physiology of endoparasitic animals. Academic Press, New York, 339 p.

Brandenburg, J. 1953. Der Parasitismus der Gattung Stylops an der Sandbiene Andrena vaga $\mathrm{Pz}$. Zeitschrift für Parasitenkunde 15: 457-475.

1956. Das endokrine System des Kopfes von Andrena vaga $\mathrm{Pz}$. (Ins. Hymenopt.) und Wirkung der Stylopisation (Stylops, Ins. Strepsipt.). Zeitschrift für Morphologie und Okologie der Tiere 45:343-364.

Bulnheim, H. P., AND J. Vavra. 1968. Infection by the microsporidian Octosporea effeminans sp. $n$. and its sex determining influence in the amphipod Gammarus duebeni. J. Parasit. 54: 241-248.

Caiger, K. M., And A. J. Alexander. 1973. The control of dominance in the brachyuran crustacean, Cyclograpsus punctatus Mil. Edw. Zoologica Africana 8:138-140.

Cattley, J. G. 1948. Sex reversal in Copepods. Nature 161:937.

Caullery, M. 1952. Parasitism and Symbiosis. Sidgwick and Jackson Ltd. London. $340 \mathrm{p}$.

Charniaux-Cotron, H. 1960. Sex determination, p. 411-447. In T. H. Waterman (ed.), The physiology of crustacea 1. Academic Press, New York.

Cheng, T. C. 1971. Enhanced growth as a manifestation of parasitism and shell deposition in parasitized mollusks. In T. C. Cheng (ed.), Aspects of the biology of symbiosis. University Park Press, London. 327 p.

- 1972. General parasitology. W. B. Saunders, Philadelphia.

Cheng, T. C., and H. A. James. 1960. The Histopathology of Crepidostomum sp. infection in the second intermediate host, Spaherium stratum. Proc. Helminthol. Soc. Wash. 27:67-68.

Cheng, T. C., ANd R. W. Snyder, Jr. 1962. Studies on host-parasite relationships between larval trematodes and their hosts. I. A review. II. The utilization of hosts glycogen by the intramolluscan larvae of Glypthelmins pennsylvaniensis Cheng and associated phenomena. Trans. Amer. Microsc. Soc. 81:209-228.

Curistensen, A. M., AND B. KanneworfF. 1965. Life history and biology of Kronborgia amphipodicola Christensen and Kannerworff (Turbellaria, Neorhabdocoela). Ophelia 2:237251.

Christie, J. R. 1936. Life history of Agamermis decaudata, a nematode parasite of grasshoppers and other insects. J. Agricult. Res. 52:161-198. DENNER, M. W. 1968. Biology of the nematode 
Mermis subnigrescens Cobb. Ph.D. Thesis, University Microfilms, Ann Arbor, Michigan.

Doanne, W. W. 1960a. Developmental physiology of the mutant female sterile (2) adipose of Drosophila melanogaster. I. Adult Morphology, longevity, egg production and egg lethality. J. Exptl. Zool. 145:1-21.

-1. 1960b. Developmental physiology of the mutant female sterile (2) adipose of Drosophila melanogaster. II. Effects of altered environment and residual genome on its expression. J. Exptl. Zool. 145:23-42.

DoGiel, V. A. 1966. General Parasitology. Academic Press, New York, $516 \mathrm{p}$.

Ebner, R. 1940. Veränderungen an Orthopteren durch parasitische Würmer. Transactions of the International Congress of Entomolgy 6: 341-471.

Einarsson, H. 1945. Euphasiacea, I. Northern Atlantic species. The Carlberg Foundation Oceanographical Expedition Round the World, 1928-1930 and previous "Dana" expeditions. Dana Rept. 5:1-185.

Etges, F., AND W. Gresso. 1965. Effects of Schistosoma mansoni infection upon fecundity in Australorbis glabratus. J. Parasit. 51:757760 .

Fischer, E. 1928. Sur les modifications d'un organisme (Crabe) enhavi par un parasite (Sacculine). Compt. rend. soc. biol. 98:837839.

Fisher, F. M. 1938. Production of host endocrine substances by parasites. In Cheng, T. C. (ed.). Ann. N.Y. Acad. Sci. 113:63-73.

- 1964. Nosema as a source of juvenile hormone in parasitized insects. Biol. Bull. 126: 235-252.

Fisher, F. M., And R. C. Sanborn. 1962. Production of insect juvenile hormone by the microsporidian parasite Nosema. Nature 194: 1193.

Fisher, R. A. 1958. The genetical theory of natural selection. Second ed. Dover, New York. $291 \mathrm{p}$.

Fontaine, A. R. 1968. A new ophiuroid host for Rhopalura ophiocomae Giard (Orthonectida: Mesozoa). J. Parasit. 54:1251-1252.

Frentz, R., AND A. Veillet. 1953. Teneur en lipide et determinisme des caracteres sexuels externes chez le crabe Carcinus maenas Pennt, parasite par le Rhizocephale Sacculina carcini Thompson. Compt. rend. 236:2168-2170.

GadGil, M., AND W. H. Bossert. 1970. Life Historical consequences of natural selection. Amer. Natur. 104:1-24.

Giard, A. 1886. De l'influence de certains parasites Rhizocephales sur les caracters sexuels exterieurs de leur hote. Compt. rend. 103:84-86. 1887. La castration parasitarie et son influence sur les caracters exterieurs du sexe male chez les Crustaces Decapodes. Bull. sci. du Dep. du Nord 18: (2) 1-28.

1889. Sur la castration parasitaire des Typhlocyba par une larve d'Hymenoptere (Aphelopus melaleucus Dalm.) et par un larve de Diptere (Ateleneura spuria Meig). Compt. rend. Acad. Sci. 109:708-710.

GiARD, A., AND J. Bonnier. 1887. Contributions a l'etude des Bopyriens. Trav. de L'Inst. Zool. Lille et Lb. Marit. Wimereux. 5:3-272.

GoERTZ, J. W. 1966. Incidence of warbles in some Oklahoma rodents. Am. Mdlnd. Nat. 75: 242-245.

Hammion, J. B. 1948. The role of testicular secretions as indicated by the effects of castration in man and by studies of pathological conditions and the short lifespan associated with maleness. Rec. Prog. Horm. Res. 3:257322.

Hamiton, J. B., R. S. Hammton, and G. E. Mestler. 1969. Duration of life and causes of death in domestic cats: influence of sex, gonadectomy and inbreeding. J. Gerontology 24:395-411.

Hartnoll, R. G. 1962. Parasitic castration of Macropodia longirostris (Fabricius) by a Sacculinid. Crustaceana 4:295-300.

- 1967. The effects of Sacculinid parasites on two Jamaican crabs. J. Linn. Soc. London (Zool.) 46:275-296.

Hattingen, R. 1956. Zentralblatt für Bakteriologie, Parasitenkunde und Infection Krankheiten. Abt. II. 109:236-249.

Hoffman, E. G., and R. M. Yancey. 1966. Ellobiopsidae of Alaskan coastal waters. Pacif. Sci. 20:70-78.

Holmes, J. C., AND W. M. Bethel. 1972. Modification of intermediate host behavior by parasites. In E. U. Canning and C. A. Wright (eds.), Behavioural aspects of parasite transmission. Zool. J. Linn. Soc. London. 51: (supl. 1) $123-149$.

Hunter, D. M., R. M. F. S. Sadietr, and J. M. Webster. 1972. Studies on the ecology of cuterebrid parasitism in deermice. Can. J. Zool. 50:25-29.

Hughes, T. E. 1940. The effects on the fat and starch metabolism of Gebia by the parasite Gyge branchialis. J. Exptl. Biol. 17:335-336.

Jennings, J. B. 1971. Parasitism and commensalism in the turbellaria. Adv. Parasit. 9:1-32.

JEPPS, M. W. 1937. On the protozoan parasites of Calanus finmarchius in the Clyde Sea area. Quart. J. Microscop. Sci., New Ser. 31679 (4) : 589-658.

KanneworfF, B. 1965. Life cycle, food and growth of the auphipod Anyselisca macrocephalo lilgeborg from the Presund. Ophelia 2:305-318.

KLoFT, W. 1949. Uber den Einfluss von Mer- 
misparasitismus auf den Stoffwechsel und die Organbildung bei Ameisen. Zeitschrift fuer Parasitenkunde 14:390-422.

KoIE, M. 1969. On the endoparasites of Buccinim undatum $\mathrm{L}$. with special reference to the trematodes. Ophelia 6:251-279.

Kornhauser, S. J. 1919. The sexual characteristics of the Membracid Thelia bimaculata Fabr. 1. External changes by Aphelopus theliae Grahan. J. Morphol. 32:531-636.

Kuris, A. M. 1974. Trophic interactions: Similarity of Parasitic Castrators to Parasitoids. Quart. Rev. Biol. 49:129-148.

Kurochkin, YU V. 1960. (The nematode Heterotylenchus pawlowskyi sp. $\mathrm{n}$. castrating fleas that transmit plague). Dokl. Akad. Nauk. S.S.R. (AIBS Translation). 135:1281-1284.

Lysaught, A. M. 1941. The biology and trematode parasites of the gastropod Littorina neritoides (L.) on the Plymouth breakwater. J. Mar. Biol. Ass. U.K. 25:41-67.

Lichtenstein, J. L. 1921. Ophryoglena collini, n. sp., parasite coelomique des larves d'Ephemeres. Compt. ren. Soc. Biol. et Fil. 85:794796.

Malm, A. W. 1881. Om Cirripeder funna vid Bohuslans Kust. Göteborgs Naturhist. Mus. zool.-zoot. Afdel. 3:26-32.

Matsumoto, K. 1952. On the sacculinization of Charibdis japonica (A. Milne-Edwards). Biol. J. Okayama Univ. 1:84-89.

-. 1953. On the epicaridization of the freshwater crab Eriocheir japonicus. Zool. Mag. Tokyo 62:354-361.

MAUChLINE, J. 1966. Thalasomyces fagei an ellobiopsid parasite of the euphassid crustacean Thysanoesa raschi. J. Mar. biol. Ass. U.K. 46: 531-539.

Murdoch, W. W. 1966. Population stability and life history phenomena. Amer. Natur. 100: 5-11.

MCClelland, G., and T. K. R. Bourns. 1969. Effects of Trychobilharia ocellata on growth, reproduction and survival of Lymanaea stagnalis, Exptl. Parasit. 24:137-146.

Nielsen, S. 1970. The effects of the Rhizocephalan parasites Peltogaster paguri Rathke and Gemnosaccus sulcatus (Lilljeborg) on five species of paguridan hosts (Crustacea: Decapoda). Sarsia 42:17-32.

Nilsson-Cantell, C. A. 1926. Uber Veränderungen der sekundären Geschlechtsmerkmale bei Paguriden durch die Einwirkung von Rhizocephalen. Ark. Zool. 18A (13):1-21.

Noble, E. R., and G. A. Noble. 1971. Parasitology, the Biology of Animal Parasites. Lea and Febiger, Philadelphia 617 p.

Okada, Y. K., and Y. Miyashita. 1935. Sacculinization in Eriocheir japonicus de Haan, with remarks on the occurrence of complete sex-reversal in parasitized male crabs. Mem. Coll. Sci. Kyoto Imp. Univ. B10:169-208.

Pald, N. B. 1948. Normal and pathologica histology of the ovaries of Bombus Latr. (Hymenopt.). Opusc. Etomol. (Sup. 7):1-101.

Pan, C. T. 1965. Studies on the host-parasite relationships between Schistosoma mansoni and the snail Australorbis glabratus. Amer. J. Trop. Med. Hyg. 14:931-976.

Perez, C. 1933. Processes de resorption pahgocytaire des oocytes dans l'ovaire chez les Macropodia sacculinees. Compt. rend. soc. biol. 112:1049-1051.

Perez, J, 1886. Des effts due parasitisme des Stylops sur les Apiaires du genre Andrena. Actes Soc. Linn. Bord. 10:21-60.

Perkins, R. C. L. 1918. Further notes on Stylops and stylopized bees. Entomol. Month. Mag. 54:115-129.

Pike, R. B. 1960. The biology and post larval development of the bopyrid parasites Pseudione affinis G. O. Sars and Hamiarthus abdominalis (Kroyer) (= Phryxus abdominalis (Kroyer)). J. Linn. Soc. London, (Zool) 44:239-251.

Puts, F. A. 1906. The modification of the sexual characters of the hermit crab caused by the parasite Peltogaster (castration parasitaire of Giard). Q. J. Microscop. Sci. 50:599-621.

Ratikalnen, M. 1966. The effect of different sexes of the parasite Elenchus tenuicornis (Kirby) on the morphology of the adult Javasella pellucida (F.) (Hom., Delpahacidae). Ann. Entomol. Fenn. 32:138-146.

RASMUSSEN, E. 1959. Behaviour of sacculinized shore crabs (Carcinus maenas Pennant). Nature $183: 479-480$.

Reinhard, E. G. 1956. Parasitic castration of Crustacea. Expl. Parasit. 5:79-107.

Reinhard, E. G., T. von Brand, and S. F. MCDuFfiE. 1947. Observations on the fat content of hermit crabs parasitized by a bopyrid. Proc. Helmithol. Soc. Wash., D.C. 14:69-73.

ReMpel, J. G. 1940. Intersexuality in Chironomidae induced by Nematode parasitism. J. Expl. Zool. 84:261-289.

ReverberI, G. 1943. Sul significato della "castrazione parassitaria." La trasformazione del sesso nei Crostacei parassitati da Bopiridi e da Rizocefali. Pubbl. staz. zool. Napoli 19: 225-316.

Rf.verberi, G. 1944/45. La determinazione del sesso ne i Crostacei e $i$ fenomeni della castrazione parassitaria. Rend. ist. lombardo sci. mat nat. 78:217-246.

Robson, G. C. 1911. The effect of Sacculina upon the fat metabolism of its host. Quart. J. Microscop. Sci. 57:267-278.

Rothschlld, A., AND M. Rothschm.d. 1939. Some observations on the growth of Peringia 
ulvae (Pennant, 1777) in the laboratory. Novitates Zool. 41:240-247.

RothschILD, M. 1936. Gigantism and variation in Peringia ulvae Pennant 1777 , caused by infection with larval trematodes. J. Mar. Biol. Ass. U.K. 30:537-546.

1938. Further observations on the effect of trematode parasites of Peringia ulvae (Pennant 1777). Nov. Zool. 41:84-102.

- 1941a. The effect of trematode parasites on the growth of Littorina neritoides (L.). J. Mar. Biol. Ass. U.K. 25:84-102.

- 1941b. Observations on the growth and trematode infections of Peringia ulvae (Pennant 1777) in a pool in the Tamar Saltings, Plymouth. Parasit. 33:406-415.

-. 1941c. Gigantism and variation in Peringia ulvae Pennant 1777 , caused by infection with larval trematodes. J. Mar. Biol. Ass. U.K. 20:537-546.

Rothschind, M., and T. Clay. 1952. Fleas, flukes and cuckoos. Macmillan, London.

Rudloff, O., ANd A. Verlete. 1954. Influence du Rhizocephale Septosaccus cuenoti sur le metabolisme lipidique du Pagure Diogenes pugilator. Compt. rend. soc. biol. 148:1464-1467.

SalT, G. 1927. The effects of stylopization on aculeate Hymenoptera. J. Exp. Zool. 48:223231.

- 1931. A further study of the effects of stylopization on wasps. J. Expl. Zool. 59:133163.

Samuelson, T. J. 1970. Peltogaster curvatus Kossman a Rhizocephalan parasite new to the Norvegian fauna with notes on the synonymy of one of the hosts, Pagurus prideauxi Leach. Sarsia 43:81-86.

voN Siebold, G. T. 1843. Uber Strepsiptera. Arch. f. Naturg, Jahrg. 9, H.1, S.:137-162.

SмIтн, G. W. 1905. Note on a gregarine $(\mathrm{Ag}$ regata inachi $\mathrm{n}$. sp.) which may cause the parasitic castration of its host (Inachus dorsettensis). Mitth. Zool. Stat. Neapel 17:406-410.

- 1913. Studies in the experimental analysis of sex. Part 10. The effect of Sacculina upon the storage of fat and glycogen, and on the formation of pigment by its host. Quart. J. Microscop. Sci. 59:267-295.

Smith, G. W., And A. H. Hamm. 1914. Studies on the experimental analysis of sex. Quart. J. Microscop. Sci. 60:435-461.

Stark, G. T. C. 1965. Dyplocotyle (Eucestoda) a parasite of Gammarus Zaddachi in the estuary of the Yorkshire Esk. Britain. Parasit. 55:415-420.

Strickland, E. H. 1911. Some parasites of Similium larvae and their effects on the development of the host. Biol. Bull. 21:302-338.

Stunkard, H. W. 1954. The life-history and systematic relations of the Mesozoa. Quart. Rev. Biol. 29:230-244.

Summerfelt, R. C., and M. C. Warner. $1970 b$. Geographical distribution and Host-parasite relationships of Plistophora ovariae (Microsporidia, Mosematidae) in Motemigonus crysoleucas. J. Wild. Dis. 6:457-465.

Trivers, R. L. 1972. Parental investment and sexual selection, p. 136-179. In B. Campbell (ed.) Sexual selection and the descent of man 1871-1971. Aldine Pbl. Co., Chicago.

VeILlet, A. 1945. Recherches sur le parasitisme des Crabes et des Galathees par les Rhizocephales et les Epicarides. Ann. inst. oceanog. Paris 22(4): 193-341.

Veillet, A., and F. Graf. 1958. Degenerescence de la glande androgene des Crustaces decapodes parasites par les Rhizocephales. Bull. Soc. scient. Nancy, N.S. 18:123-127.

Vevers, H. G. 1951. The biology of Asterias rubens L. 11. Parasitization of the gonads by the ciliate Orchitophya stellarum Cepede. J. Mar. Biol. Assoc. U.K. 29:619-624.

Wang, Der I., and F. E. Moeller. 1970. The division of labor and queen attendance behavior of nosema-infected worker honey bees. $\mathbf{J}$. Econ. Entomol. 63:1539-1541.

Wecker, S. C. 1962. The effects of bot fly parasitisms in a local population of the whitefooted mouse. Ecology 43:561-565.

WeICH, H. E. 1959. Taxonomy, life cycle, development and habits of two new species of Allantonematidae (Nematoda) parasitic in drosophilid flies. Parasitology 49:83-103.

- 1965. Eutomophilic nematodes. Amer. Rev. Ent. 10:275-302.

WheELeR, W. M. 1910. The effects of parasitic and other kinds of castration in Insects. J. Exp. Zool. 8:377-438.

Williams, G. C. 1966a. Adaptation and natural selection. Princeton Univ. Press, Princeton, New Jersey. 307 p.

- $1966 b$. Natural selection, the costs of reproduction and a refinement of Lack's principle. Amer. Natur. 100:687-690.

WOODHEAD, A. E. 1930. Life history studies on the trematode family Bucephalidae. No. II. Trans. Am. Micro. Soc. 49:1-17.

Wright, C. A. 1971. Flukes and snails. Science of biology series No. 4. George Allen and Unwin Ltd., London, p. 168.

WüLKER, W. 1961. Untersuchungen über die Intersexualität der Chironomiden (Dipt.) nach Paramermis-Infektion. Archiv. Hydrobiol. Sup. 25:127-181.

- 1962. Parasitäre und nicht parasitäre geschlechtliche Aberrationem bei Chironomiden. Zool. Anz. Sup. 25:132-139.

-1964. Parasite-induced changes of internal and external sex characteristics in insects. Exp. Parasitol. 15:561-597. 